\title{
Pollution of the Chari River in the Slaughterhouse Farcha (N'djamena) in Chad
}

\author{
Tchadanaye New Mahamat', Noumi Guy Bertrand ${ }^{2, ~ *}$, Paloumi Yabe ${ }^{1,2}$ \\ ${ }^{1}$ Department of Chemistry, Faculty of Exact and Applied Sciences, University of N'djamena, N'djamena, Chad \\ ${ }^{2}$ Department of Chemistry, Faculty of Science, University of Ngaoundere, Ngaoundere, Cameroon
}

Email address:

gnoumi@yahoo.fr (N. G. Bertrand)

To cite this article:

Tchadanaye New Mahamat, Noumi Guy Bertrand, Paloumi Yabe. Pollution of the Chari River in the Slaughterhouse Farcha (N'djamena) in Chad. American Journal of Environmental Protection. Vol. 5, No. 1, 2016, pp. 11-19. doi: 10.11648/j.ajep.20160501.12

\begin{abstract}
This study was carried out to evaluate the influence of the discharge of effluents Farcha slaughterhouses pollution of the Chari River. To overcome this, water and sediment samples were taken upstream to the outlet and downstream of Farcha slaughterhouse. These samples were subjected to some physicochemical analysis. Slaughterhouse effluent showed a Chemical Oxygen Demand (COD) ranging from $96 \mathrm{mg} . \mathrm{L}^{-1}$ to $100 \mathrm{mg} . \mathrm{L}^{-1}$; Biochemical Oxygen Demand (BOD 5$) 54 \mathrm{mg} . \mathrm{L}^{-1}$ to $70 \mathrm{mg} . \mathrm{L}^{-1}$ and the suspended solids (TSS) $64 \mathrm{mg} . \mathrm{L}^{-1}$ to $108 \mathrm{mg} \cdot \mathrm{L}^{-1}$. The physicochemical characterization of water samples Chari gave a change in hydrogen potential $(\mathrm{pH})$ between 6 to 7 ; a temperature ranging from $28.35^{\circ} \mathrm{C}$ to $28.70^{\circ} \mathrm{C}$ with an electric conductivity ranging from $50 \mu \mathrm{S} . \mathrm{cm}^{-1}$ to $129 \mu \mathrm{S} . \mathrm{cm}^{-1}$. The dissolved oxygen levels in water shows an appreciable oxygenation (5.02 - $\left.7.37 \mathrm{mg} \mathrm{O}_{2} . \mathrm{L}^{-1}\right)$. As the mineral substances, the chloride ions $\left(\mathrm{Cl}^{-}\right)$vary from $9.05 \mathrm{mg} . \mathrm{L}^{-1}$ to $29.25 \mathrm{mg} . \mathrm{L}^{-1}$; ferrous ions $\left(\mathrm{Fe}^{2+}\right)$ of $0.48 \mathrm{mg} . \mathrm{L}^{-1}$ to $11.10 \mathrm{mg} . \mathrm{L}^{-1}$; sulphate ions $\left(\mathrm{SO}_{4}{ }^{2-}\right)$ of $21.50 \mathrm{mg} . \mathrm{L}^{-1}$ to $38 \mathrm{mg} . \mathrm{L}^{-1}$; phosphate ions $\left(\mathrm{PO}_{4}{ }^{3-}\right)$ of $20.45 \mathrm{mg} / \mathrm{L}$ to $84.35 \mathrm{mg} / \mathrm{L}$; nitrate ions $\left(\mathrm{NO}_{3}^{-}\right)$of $15 \mathrm{mg} . \mathrm{L}^{-1}$ to $39.50 \mathrm{mg} . \mathrm{L}^{-1}$. In opposite, the concentrations of nitrite $\left(\mathrm{NO}_{2}^{-}\right)$increased from $7.45 \mathrm{mg} . \mathrm{L}^{-1}$ to $13 \mathrm{mg} . \mathrm{L}^{-1}$; that of ammonium ions $\left(\mathrm{NH}_{4}^{+}\right) 1.49 \mathrm{mg} . \mathrm{L}^{-1}$ to $4.95 \mathrm{mg} . \mathrm{L}^{-1}$. The concentrations of dissolved ions showed higher values in July than in September. We observed significant variations in these parameters, some of which values were in excess of the WHO standard. However; the rate of $\mathrm{COD} / \mathrm{BOD}_{5}=1.67$ show that these wastewater Farcha slaughterhouses are biodegradable.
\end{abstract}

Keywords: Chari River, N'djamena, Slaughterhouse, Effluent, Physicochemical Parameters

\section{Introduction}

Generally, the aquatic environment quality is significantly affected by several natural and anthropic activities which provide many contaminants [1-4].

The Chari River (1200 km) undergoes physical, chemical and biological constraints through several cities in Chad. This river is the main tributary of Lake Chad, which is experiencing a significant crowding in recent years. The lake area who was $25,000 \mathrm{~km}^{2}$ in 1960 decreased to $1,500 \mathrm{~km}^{2}$ in 2000 [5]. At the city of N'djamena, wastewater is discharged directly into the river or in the gutters drain rainwater draining the Chari River. These domestic water from hotels, hospitals, households and other domestic purposes. Also, diseases such as gastroenteritis and typhoid were detected among residents because of the downstream water consumption from the river and slaughterhouses Farcha [6].

Slaughterhouses Farcha is a typical example of industry where the water is used for washing the by-products (offal) and disposal of waste (faeces, debris paunch and blood). Built in 1958, the slaughterhouse Farcha (La Société Moderne des Abattoirs SMA/AFF) has a capacity of 110 tons of meat per day and daily production is about 200 cattle, 200 to 300 small ruminants and 30-80 camels [7]. Located on the river, the slaughterhouse Farcha is connected to the Chari River through its outflow channel. The effluents of these slaughterhouses are then discharged into the Chari River without prior treatment. Thus the water system is subject to important risks of pollution that threatens water quality. This study thus proposes to contribute to the assessment of pollution in the river Chari by the slaughterhouse Farcha (N'djamena) in Chad.

\section{Materials and Methods}

\subsection{Overview of the Study Area}

The Chari River $(1200 \mathrm{~km})$ is our environmental space and 
study more precisely the area from the 27 camp on the side of the right bank of the river alongside the zootechnical laboratory Farcha, slaughterhouse outfall Farcha up Nursery Milezi. This area is included in the first district of the city of N'djamena. The Chari River, very heterogeneous, with an average flow of $537 \mathrm{~m}^{3} \cdot \mathrm{s}^{-1}$ is weak and unstable because of natural hazards that describe climate variability (evaporation, climate change, inter annual variation in rainfall distribution), and intensification of market garden [8]. All industrial effluents, sewage and household waste are discharged into the river without proper treatment. La Société Moderne des Abattoirs of Farcha is one of the food industry do not have wastewater treatment plant that discharges its effluents directly into the liquid Chari River.

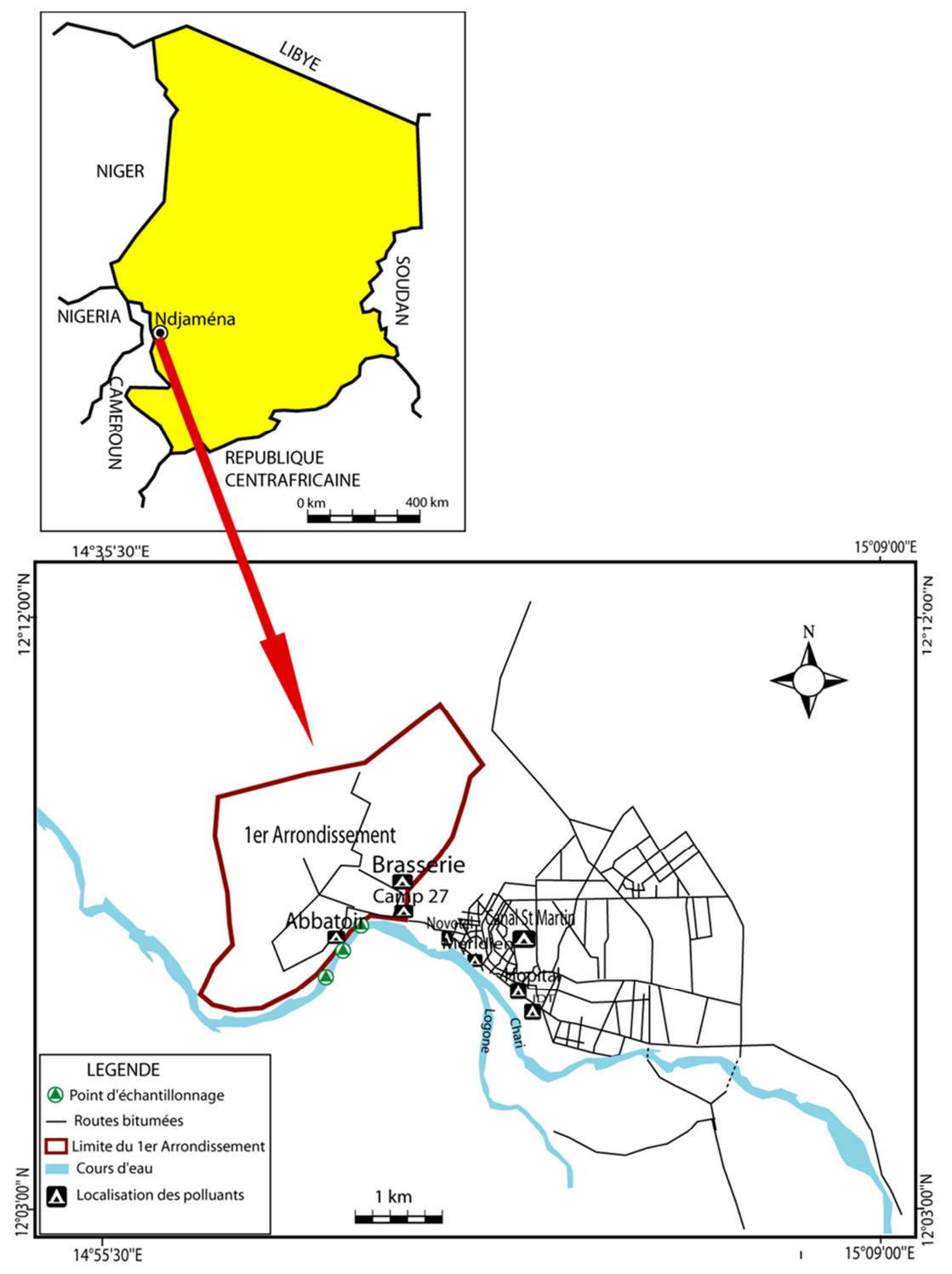

Figure 1. Study area and location of sampling points.

Two sets of samples were taken during the study, one in low water period (July 2015) and the other in winter period (September 2015). The water samples were collected in polyethylene bottles of $250 \mathrm{~mL}$, previously washed and

\subsection{Sampling}

The selection of sample points was made taking into account the location of the wastewater discharge point slaughterhouses Farcha and various identified activities (domestic sewage, industrial, agricultural, leaching) in the area. Thus, three points (AMO, EXU and AVA) upstream to the outlet and downstream slaughterhouses were selected for this study. These points have been designated as follows: P1 (AMO): Sampling point upstream slaughterhouses, $100 \mathrm{~m}$ from the outfall; P2 (EXU): Outlet slaughterhouses Farcha and P3 (AVA): Downstream sampling point slaughterhouses, located $100 \mathrm{~m}$ from the outfall.

Figure 1 shows the map of the study area and the location of sampling points. rinsed with distilled water. All samples were stored at low temperature $\left(4^{\circ} \mathrm{C}\right)$ and transported to the laboratory. These water samples were filtered using a Whatman filter paper (1.2 $\mu \mathrm{m}, \mathrm{GF} / \mathrm{C}) .50 \mathrm{~mL}$ of each sample was acidified with 
concentrated hydrochloric acid $(0.5 \mathrm{~mL})$ and stored in vials until analysis [9]. About $100 \mathrm{~g}$ sediment were collected in the same water sampling points and stored in polyethylene plastic and were then dried 24 hours in the laboratory. The dry sediment was ground, sieved through a sieve with $1 \mathrm{~mm}$ mesh. A mixture of $10 \mathrm{~g}$ of sediment and $50 \mathrm{~mL}$ of ammonium acetate was subjected to stirring for 1 hour, then filtered through a filter paper (Whatman, GF/C, $47 \mathrm{~mm}$ ) in the $100 \mathrm{~mL}$ flask. For each sample (water, sediment) a triplicate of samples was taken.

\subsection{Analytical Methods}

The physicochemical study of water was done on sixteen parameters: temperature, hydrogen potential $(\mathrm{pH})$, conductivity (EC), turbidity and dissolved oxygen have been measured in the field. The suspended solids (TSS), nitrogen forms $\left(\mathrm{NO}_{3}^{-}, \mathrm{NO}_{2}^{-}, \mathrm{NH}_{4}^{+}\right)$, phosphate $\left(\mathrm{PO}_{4}{ }^{3-}\right)$, sulphates $\left(\mathrm{SO}_{4}{ }^{2-}\right)$, chloride $\left(\mathrm{Cl}^{-}\right)$, iron $\left(\mathrm{Fe}^{2+}\right)$ and organic pollution $\left(\mathrm{BOD}_{5}, \mathrm{COD}\right)$ was carried out in Laboratory of Water and Environment of the Faculty of Exact Sciences and Applied of the University of N'djamena following the technics and methods described by Rodier [9]. The $\mathrm{pH}$, conductivity and temperature of the water was measured using a $\mathrm{pH}$ meter Cyberscan-pH110 brand fitted with a thermometer, and a conductivity meter. Dissolved oxygen was measured using a HACH Oximeter. Phosphates, ammonium ions, nitrates, nitrites, sulphates, chlorides, iron were measured by the photometer-7100 (Palintest). The chemical oxygen demand, suspended solids were measured by spectrophotometer $\mathrm{HACH}$ brand. The turbidity was read by the photometer7100. The biochemical oxygen demand was measured by a measuring BOD in a thermoregulatory AQUALYTIC under temperature of $20^{\circ} \mathrm{C}$.

\section{Statistical Analysis}

The results of this work have been analysed by the software Microsoft Office Excel 2007. The principal components analysis (PCA) was performed using the Statgraphics software and XLSTAT 2007 version 8.04 software.

\section{Results and Discussion}

\subsection{Water Temperature}

It's important to know the water temperature with good accuracy because it is an important ecological factor. Temperatures range between $28.35^{\circ} \mathrm{C}$ and $28.64^{\circ} \mathrm{C}$ in July and between $28.45^{\circ} \mathrm{C}$ and $28.70^{\circ} \mathrm{C}$ for the month of September (Figure 2). The high value is EXUj, this can be explained by the release of water from the slaughterhouse in contact with the waters of the river Chari. In September the maximum is AMOs and this could be reflected in releases of the upstream brewery slaughter or time of sampling. These results are close to the results of previous work: $27^{\circ} \mathrm{C}$ to $29,14^{\circ} \mathrm{C}$ [8]. However, the values obtained are less than $30^{\circ} \mathrm{C}$ (WHO Standard) [10].

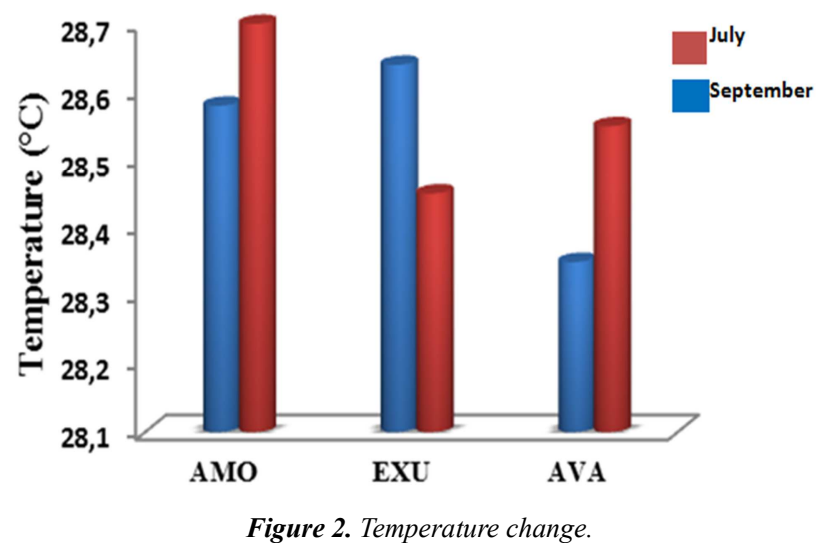

\subsection{Hydrogen Potential}

This parameter determined a large number of physical and chemical equilibria, and depends on many factors, including temperature and the source of the water, it represents an important indication as regards the aggressiveness of the water (Suitability dissolve the limestone) $[11,12]$. The $\mathrm{pH}$ values (Figure 3) ranges from 7.10 to 7.28 in July and 6.96 to 7.15 in September. Regarding the series of July, the $\mathrm{pH}$ decreases from upstream to downstream in AMOj (7.28). The same decrease is observed in September with a small point AVAs sudden jump (7.15). These variations may be due to the leaching activity in the zone, using basic products and the other hand to the photosynthetic activity which releases $\mathrm{CO}_{2}$ resulting in a $\mathrm{pH}$ increase. The results obtained at different sampling points seem to be in agreement with the water agency and the WHO limit ( $\mathrm{pH}<8.5)$. These results are comparable to those of work [8] on the Chari River (7.03 to 8.14).

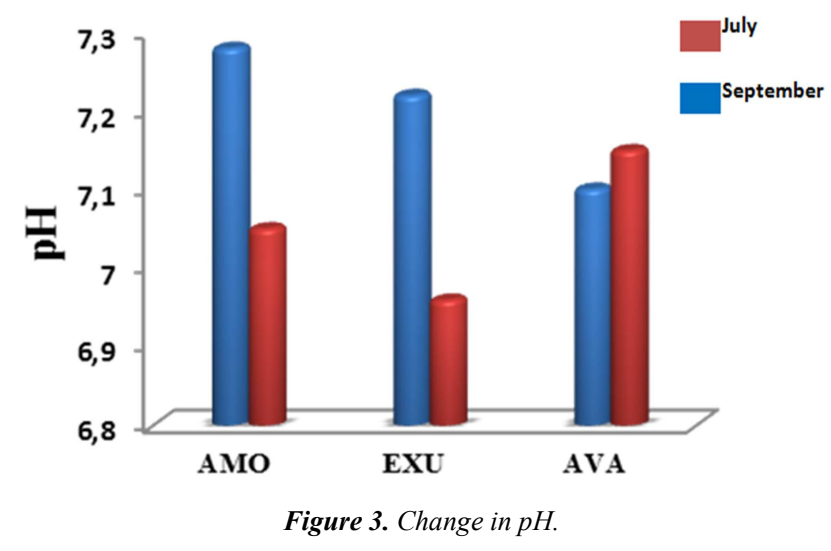

\subsection{The Electrical Conductivity}

The conductivity measurement is a good assessment of the degree of mineralization of water which is each ion by its concentration and specific conductivity. The recorded average values (Figure 4) fluctuate between $125.25 \mu \mathrm{S} / \mathrm{cm}$ (EXUj) and $125.15 \mu \mathrm{S} / \mathrm{cm}$ (AVAj) for the series in July. There is a drop in conductivity in September, while maintaining a growth upstream respectively downstream $50.90 \mu \mathrm{S} / \mathrm{cm}$ (AMOs); $53.80 \mu \mathrm{S} / \mathrm{cm}$ (EXUs); and 69.70 $\mu \mathrm{S} / \mathrm{cm}$ (AVAs). The higher values of conductivity measured in July may be explained by the increase in temperature causes an 
increase in dissolved minerals from the IDT (Chad printing press) and zootechnical laboratory by water evaporation phenomenon. On the one hand, the relatively low values in September can be justified by the decrease in temperature. Furthermore the dilution effect during the flood period, waters Chari would have led to a decrease in the concentrations of dissolved ions. The values obtained are below the $\mathrm{WHO} / \mathrm{Chad}$ Directive (2007) set to $1000 \mu \mathrm{S} / \mathrm{cm}$ for surface waters and confirm previous work [8] conducted on the Chari River. However, higher values $(360 \mu \mathrm{S} / \mathrm{cm})$ were obtained from slaughterhouse waste of Kenitra [13].

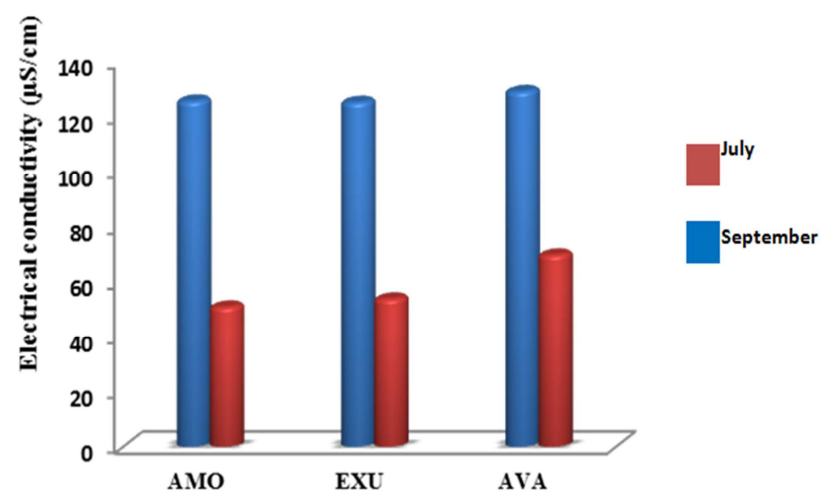

Figure 4. Change in electrical conductivity.

\subsection{Turbidity}

Turbidity is a sensory parameter and an expression of the optical properties of a water absorbing and/or diffusing light is due to the presence of finely-divided suspended solids (clays, silts) [14]. Analysis of variance of the turbidity values of water samples summarized in figure 5 shows that there is a significant difference $(p<0.05)$ between the two sample sets. High values (Figure 5) of the turbidity of the different sampling points are observed at the outlet in July (415 NTU) until September (127.50 NTU). This turbidity is a function of seasons and sampling periods. Indeed, high turbidity were observed water withdrawn in July which marks the beginning of the Chari flood. The increased turbidity results from rainwater run-off phenomenon and that of re-suspension of sediments previously deposited along the Chari River. They are much more marked at the outlet of slaughterhouses due to suspended solids discharges from the slaughterhouses.

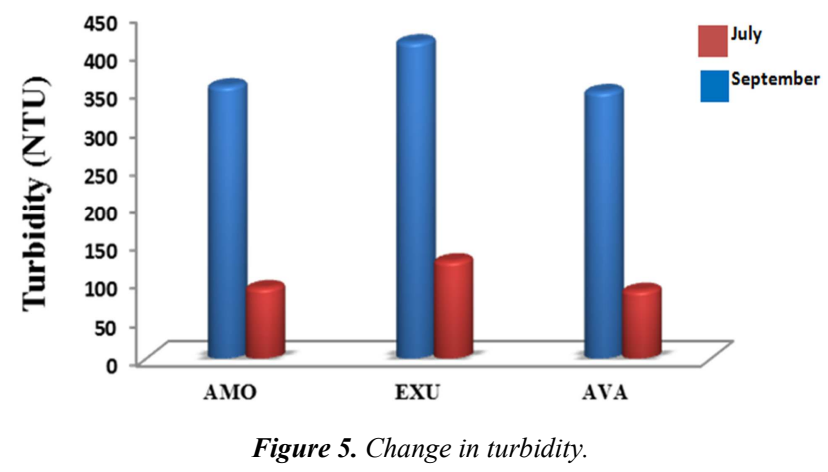

\subsection{The Suspended Solids (TSS)}

The amount of suspended solids depends on the nature of the area to be crossed, season, rainfall, flow water regime, the nature of releases, etc. The corresponding averages (Figure 6) in each series are respectively $82 \mathrm{mg} . \mathrm{L}^{-1}$ and $84 \mathrm{mg} . \mathrm{L}^{-1}$ for the month of July and September and show that there is no significant difference $(\mathrm{p}<0.05)$ the two sample sets. Changes in levels of suspended solids (TSS) Chari River water around the Farcha slaughterhouses are almost similar for both periods: the maximum values are recorded at the outlet of the slaughterhouse. These high levels may be the result of a brutal hydrological event (flood), the burden of TSS can be attributed to intense erosion and runoff and gutters of the city, following rainstorms that cause an increase suspended solids. This is likely due to effluents from slaughterhouses and liquid waste generated by coastal centers (IDT, Chad Brewery) as well as solid waste randomly deposited on the banks and gutters installed upstream slaughterhouses.
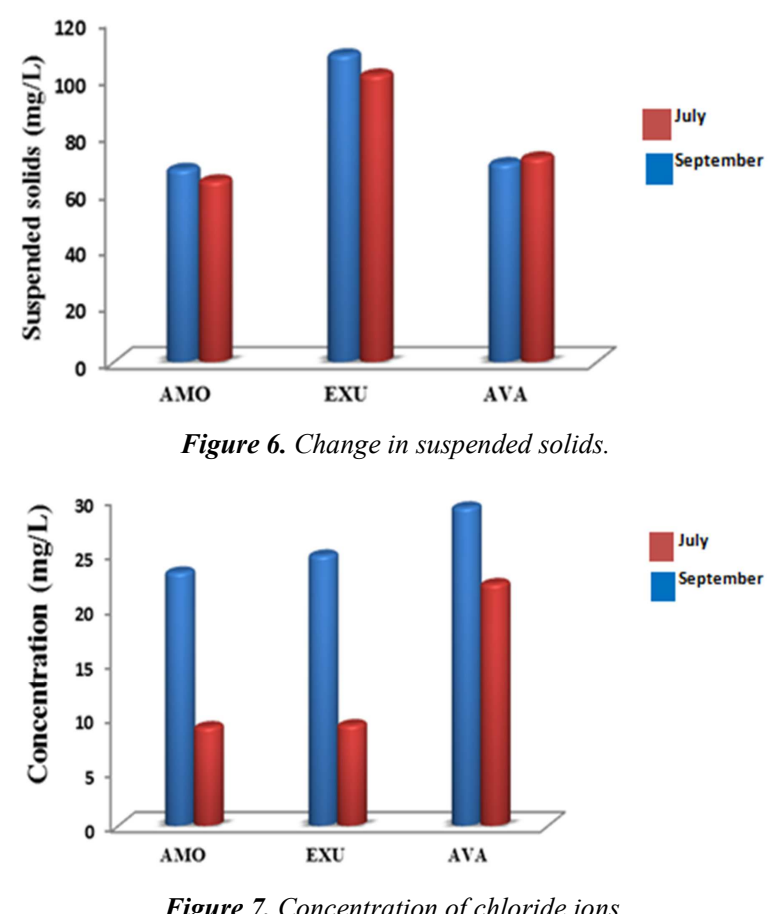

\subsection{Chloride Ions $(\mathrm{Cl})$}

The chlorides are often used as an indicator of pollution. The concentrations of chloride ions into the waters identified (Figure 7) show the upstream downstream of $23.30 \mathrm{mg} . \mathrm{L}^{-1}$ to $29.25 \mathrm{mg} . \mathrm{L}^{-1}$ in July. This variation is also observed in September with the high content of $22.24 \mathrm{mg} . \mathrm{L}^{-1}$ developed AVAs. High concentrations are recorded in the downstream part of slaughterhouses could indicate the contribution of slaughterhouses both from urban and industrial. For both study periods, chlorides record levels that do not exceed WHO standards set at $250 \mathrm{mg} . \mathrm{L}^{-1}$. These levels are close to the work of Ngaram et al. (2011) [8] and Belghyti et al. (2009) [13] performed respectively on the Chari River and wastewater slaughterhouse Kenitra. 


\subsection{The Iron Ions $\left(\mathrm{Fe}^{2+}\right)$}

Analysis variance of water samples iron contents (Figure 8) shows that there is a significant difference $(\mathrm{p}<0.05)$ between the two sampling periods. Indeed, the concentrations obtained (Figure 8) shows that concentrations ranged from $(7.25 \pm 2.19) \mathrm{mg} . \mathrm{L}^{-1}$ and $(11.10 \pm 2.68) \mathrm{mg} . \mathrm{L}^{-1}$ in July when they are between $(0.48 \pm 0.60) \mathrm{mg} . \mathrm{L}^{-1}$ and $(1.70 \pm 0.56)$ mg. $\mathrm{L}^{-1}$ in September. The low values obtained in September may be justified by the dilution effect. The September month actually marks the Chari flood waters. The concentration is always high at the outlet compared to other points which attests that intakes of iron by slaughterhouses Farcha are not negligible. The iron contents of the Chari river water exceed the WHO limit $\left(0.30 \mathrm{mg} . \mathrm{L}^{-1}\right)$ for consumer waters. These results are lower than those of the work Haoua et al. (2011) [15] on the Niger River (39.19 mg. $\left.\mathrm{L}^{-1}\right)$.
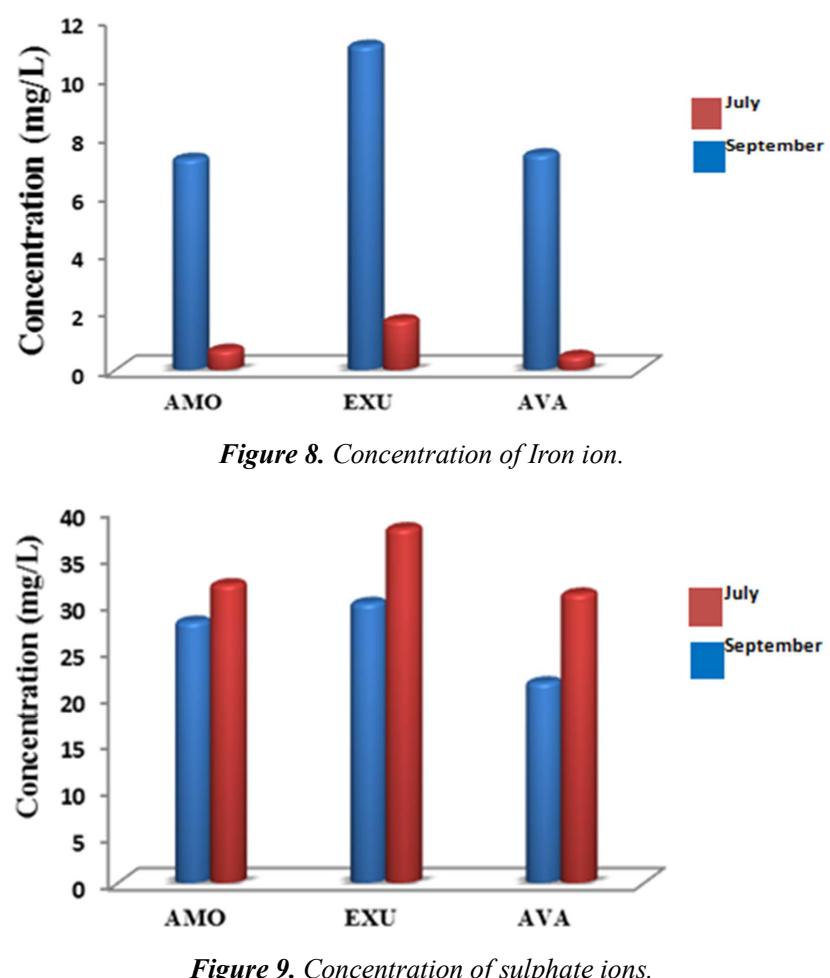

\subsection{The Sulphate Ions $\left(\mathrm{SO}_{4}{ }^{2-}\right)$}

The concentrations of sulphate ions (Figure 9) show that they are higher in September compared to July and showed a significant difference $(p<0.05)$ between the two periods. The average values range from $(21.50 \pm 2.10) \mathrm{mg} . \mathrm{L}^{-1}$ to $(30.00 \pm 0.52) \mathrm{mg} . \mathrm{L}^{-1}$. In September they vary from $(31.00 \pm$ $6.70) \mathrm{mg} . \mathrm{L}^{-1}$ to $\left(38.00 \pm 3.50 \mathrm{mg} . \mathrm{L}^{-1}\right)$. The highest values observed at the outlet of slaughterhouses, may result in the intake of sulphate ions from effluents slaughterhouses. The high levels in September suggest also consider other source discharges from the brewery. We find that the average concentrations of sulphate decreased from upstream downstream slaughterhouses. This may be due to settling or to any complexion sulphates along the path of water flow. The average levels of sulphate are much lower than the limit value set by the WHO as regards the quality of drinking water $\left(500 \mathrm{mg} . \mathrm{L}^{-1}\right)$.

\subsection{The Phosphate Ions $\left(\mathrm{PO}_{4}{ }^{3-}\right)$}

The phosphate concentrations in the waters of the Chari River in the vicinity of the discharge of slaughterhouses Farcha range from $(20.45 \pm 5.02) \mathrm{mg} . \mathrm{L}^{-1}$ to $(32.60 \pm 6.92)$ mg. $\mathrm{L}^{-1}$ and $(42.85 \pm 17.32) \mathrm{mg} . \mathrm{L}^{-1}$ to $(85.35 \pm 9.40) \mathrm{mg} . \mathrm{L}^{-1}$, respectively, for the month of July and September (Figure 10). First, these high levels in September can be justified by the use of phosphate fertilizers in the area at that time. On the other hand, this strong availability of phosphates can be explained by urban waste of the city in addition to contributions slaughterhouses. These results are much higher than those of previous work (Ngaram et al., 2011) [8].

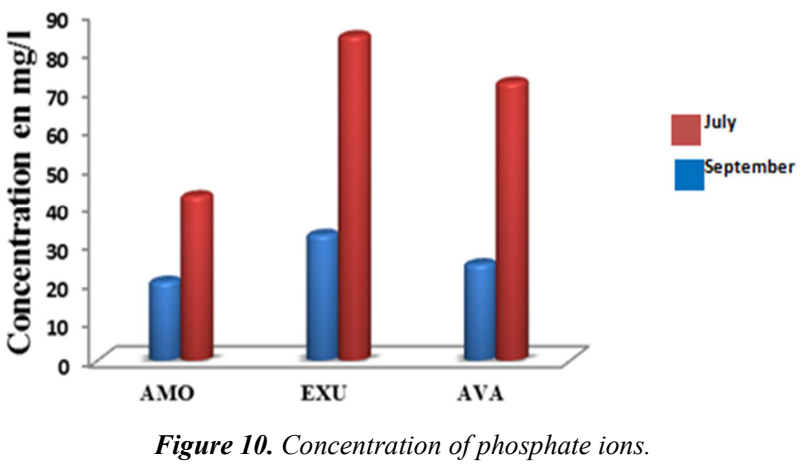

\subsection{Nitrogen Forms}

\subsubsection{Nitrate Ions $\left(\mathrm{NO}_{3}^{-}\right)$}

The growth is observed in the concentration of nitrates upstream downstream with a statistically significant difference $(p<0.05)$ during the two sampling periods (Figure 11a). Average grades range from $(15.00 \pm 7.07) \mathrm{mg} . \mathrm{L}^{-1}$ to $(27.00 \pm 0.00) \mathrm{mg} . \mathrm{L}^{-1}$ points in July. They range from $(20.00$ $\pm 1.41) \mathrm{mg} . \mathrm{L}^{-1}$ to $\left(39.50 \pm 1.76 \mathrm{mg} . \mathrm{L}^{-1}\right)$ in September. The high values in both periods could be attributed to releases from bellies, manure, urine, faeces of animals contained in effluent from slaughterhouses. This can also be justified by discharges of wastewater from hotels, gutters, hospital (HGRN), much to the leaching of fertilizers used in agricultural soils situated on the outskirts of the Chari which have been no treatment. These results are in agreement with those of Ngaram et al. (2011) [8] on the Chari River (21.60 mg. $\left.\mathrm{L}^{-1}\right)$. Nitrate levels recorded in Chari surface water at the outlet of Farcha slaughterhouses are well above the standard suggested by WHO (1-10 mg.L $\left.\mathrm{L}^{-1}\right)$ [10].

\subsubsection{Nitrite Ions $\left(\mathrm{NO}_{2}^{-}\right)$}

Analysis of variance of the concentrations of nitrite ions in water shows that there is not a statistically significant difference $(p<0.05)$ for the two series (Figure 11b). Indeed, concentrations of nitrites analysed waters vary between 7.45 $\pm 8.83 \mathrm{mg} . \mathrm{L}^{-1}$ to $10.80 \pm 1.13 \mathrm{mg} . \mathrm{L}^{-1}$ and of $9.30 \pm 42 \mathrm{mg} . \mathrm{L}^{-1}$ to $13.21 \pm 20.50 \mathrm{mg} . \mathrm{L}^{-1}$, respectively, during the months of July and September. These values are beyond the WHO threshold $\left(3 \mathrm{mg} . \mathrm{L}^{-1}\right)$. Nitrites are generally from the either of 
an incomplete degradation of ammonia or a nitrate reduction, they represent only an intermediate stage and readily oxidized to nitrate [16]. The high concentrations of nitrites encountered, could be explained by the fact that they come from effluent from slaughterhouses and nutrient rich agricultural area NPK (vegetable crops along the river).

\subsubsection{Ammonium ion $\left(\mathrm{NH}_{4}^{+}\right)$}

Analysis of variance of ammonium ion concentrations show a statistically significant difference $(p<0.05)$ between two sampling series (Figure 11c). Average grades vary
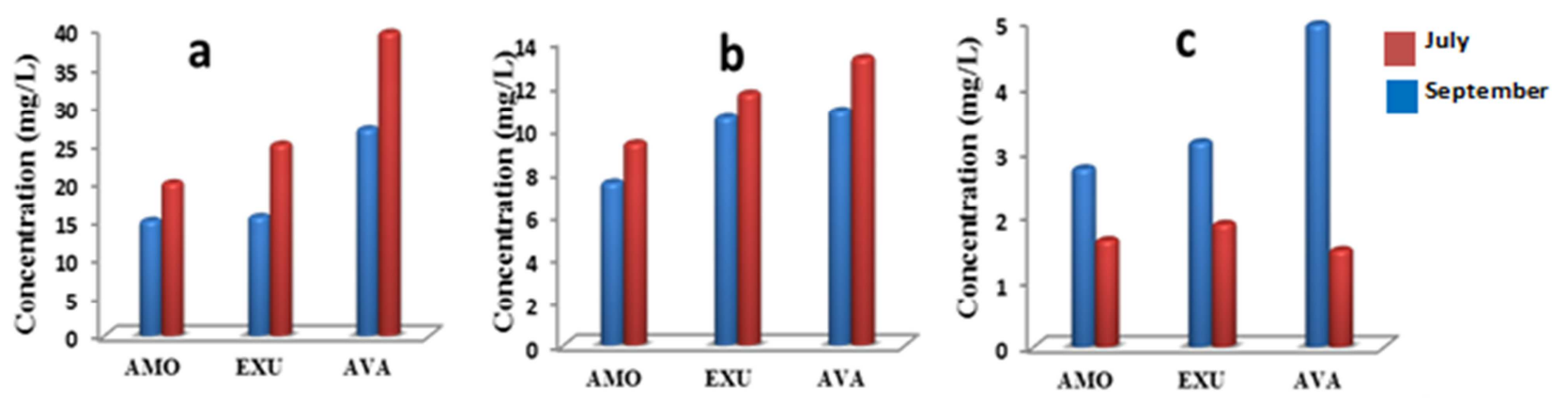

Figure 11. Ion concentration a) nitrate: b) nitrite; c) ammonium.

\subsection{Evaluation of Organic Waste Water Pollution}

\subsubsection{The Dissolved Oxygen Content}

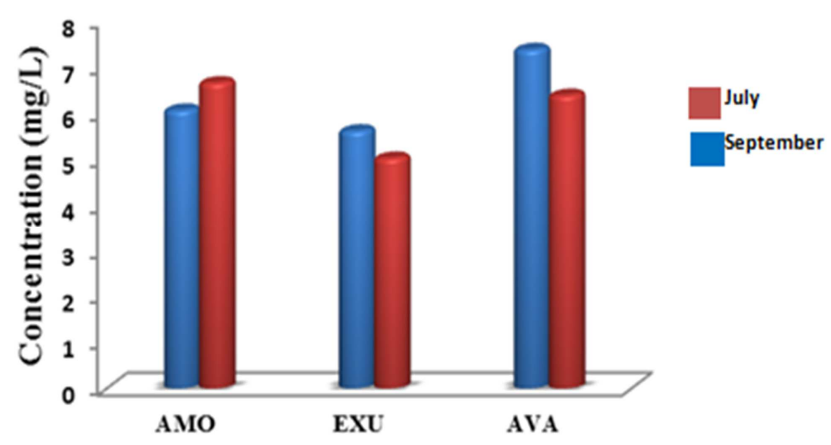

Figure 12. Variation of the dissolved oxygen concentration of water samples.

Analysis of variance of dissolved oxygen concentrations (Figure 12) shows that there is not a statistically significant difference $(p<0.05)$ in the two sampling periods. The average contents of dissolved oxygen in various samples range from: $5.61 \pm 0.42 \mathrm{mg} . \mathrm{L}^{-1}$ to $7.37 \pm 0.70 \mathrm{mg} . \mathrm{L}^{-1}$ in July and $5.02 \pm 0.41 \mathrm{mg} . \mathrm{L}^{-1}$ to $6.65 \pm 0.15 \mathrm{mg} . \mathrm{L}^{-1}$ in September. These results show regular and close values of previous work $5.97 \mathrm{mg} . \mathrm{L}^{-1}$ to $7.97 \mathrm{mg} . \mathrm{L}^{-1}$ conducted on the waters of the Chari River in the city of N'djamena [8]. This may be mainly due to the decrease of the water temperature; as a cold water has a higher amount of dissolved oxygen than warm water [17]. The recorded average levels are above $5 \mathrm{mg} . \mathrm{L}^{-1}$, which is acceptable to the $\mathrm{WHO} / \mathrm{Chad}$ standard. However, the data obtained show that river waters are polluted by slaughterhouses and wastewater of industrial origin, urban upstream slaughterhouses. between $2.75 \pm 0.63 \mathrm{mg} . \mathrm{L}^{-1}$ to $4.95 \pm 0.63 \mathrm{mg} . \mathrm{L}^{-1}$ and $1.49 \pm$ $1.12 \mathrm{mg} . \mathrm{L}^{-1}$ to $1.89 \pm 1.26 \mathrm{mg} . \mathrm{L}^{-1}$. The ammonium ion high values in July translate the incomplete degradation process of organic matter. The grades obtained in September are lower than in the period July especially downstream of the study area. Which reflects the effect of dilution and shows oxygenation of water thus causing the oxidation of nitrogen. The limit set by the WHO standard is $10 \mathrm{mg} . \mathrm{L}^{-1}$ for the protection of contamination of aquatic organisms. 
water samples are from $97.80 \pm 0.50 \mathrm{mg} . \mathrm{L}^{-1}$ and $99.10 \pm 1.30$ $\mathrm{mg} . \mathrm{L}^{-1}$ in July and between $96.30 \pm 0.56 \mathrm{mg} . \mathrm{L}^{-1}$ to $100.70 \pm$ $0.70 \mathrm{mg} . \mathrm{L}^{-1}$ in September. The increase of COD can be explained by the additional input of organic matter slaughterhouses and runoff materials during the dry season and entrained by rainwater. Note that the results are superior to those obtained previously by Ngaram et al. (2011) [8] on the Chari (30.50-30.75 mg. $\left.\mathrm{L}^{-1}\right)$.

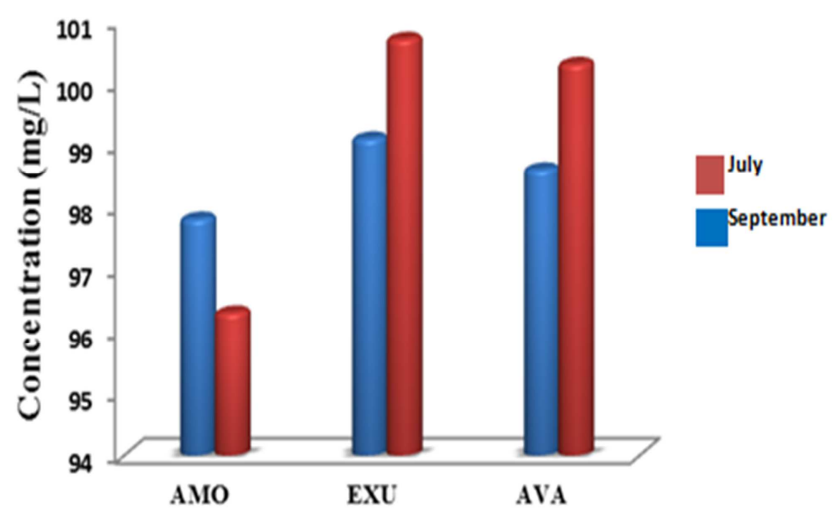

Figure 14. Variation of the COD content of the water samples.

\subsubsection{Ratio $\mathrm{COD} / \mathrm{BOD}_{5}$}

For a better understanding of the origin of the waste water, the calculation of $\mathrm{COD} / \mathrm{BOD}_{5}$ has very important interests. The ratio $\mathrm{COD} / \mathrm{BOD}_{5}$ can estimate the biodegradability of a given effluent. It is generally agreed the following limits: $2>$ COD/BOD5: the effluent is easily biodegradable; $2<$ $\mathrm{COD} / \mathrm{BOD}_{5}<3$ : effluent is biodegradable with selected strains and $3<\mathrm{COD} / \mathrm{BOD}_{5}$ : the effluent is not biodegradable [18].

The wastewater from the slaughterhouse Farcha have ratios equal to $1.47 ; 1.64$ and 1.55 respectively upstream, at the outlet and downstream of the slaughterhouse. These reports from different points are lower than 2 which showed the wastewater Farcha slaughterhouses are readily biodegradable. However, a biological treatment is absolutely necessary.

\section{Characterization of Sediments}

The concentrations of different parameters are relatively low for the July season (Figure 15).

These levels are much observed in September. This may be due to a transport of these nutrients by rain runoff from the market gardens of the intense agriculture made by the residents and the massive use of detergents by money along the river through the city N'djamena. These concentrations ranged from $0.021 \mathrm{mg} . \mathrm{L}^{-1}$ (AMOj) to $0.16 \mathrm{mg} \cdot \mathrm{L}^{-1}$ (AVAs) for nitrite. They range from $0.23 \mathrm{mg} \cdot \mathrm{L}^{-1}$ (AVAj) to $4.20 \mathrm{mg} \cdot \mathrm{L}^{-1}$ (AVAs) for nitrates. Phosphates vary from $1.90 \mathrm{mg} \cdot \mathrm{L}^{-1}$ (AMOj) to $5.20 \mathrm{mg} . \mathrm{L}^{-1}$ (AVAs). Sulphates grow $1.20 \mathrm{mg} / \mathrm{L}$ (AMOj) to $4.26 \mathrm{mg} . \mathrm{L}^{-1}$ (AVAs) and chlorides range from 1.80 $\mathrm{mg} \cdot \mathrm{L}^{-1}$ (AMOj) to $3.50 \mathrm{mg} \cdot \mathrm{L}^{-1}$ (AVAs). The ammoniacal nitrogen $3 \mathrm{mg} \cdot \mathrm{L}^{-1}$ (AVAj) is reduced to $0.27 \mathrm{mg} \cdot \mathrm{L}^{-1}$ (AVAs). While low concentrations of iron $0.01 \mathrm{mg} . \mathrm{L}^{-1}$ (AMOj) increased to $9.20 \mathrm{mg} \cdot \mathrm{L}^{-1}$ (AVAs).

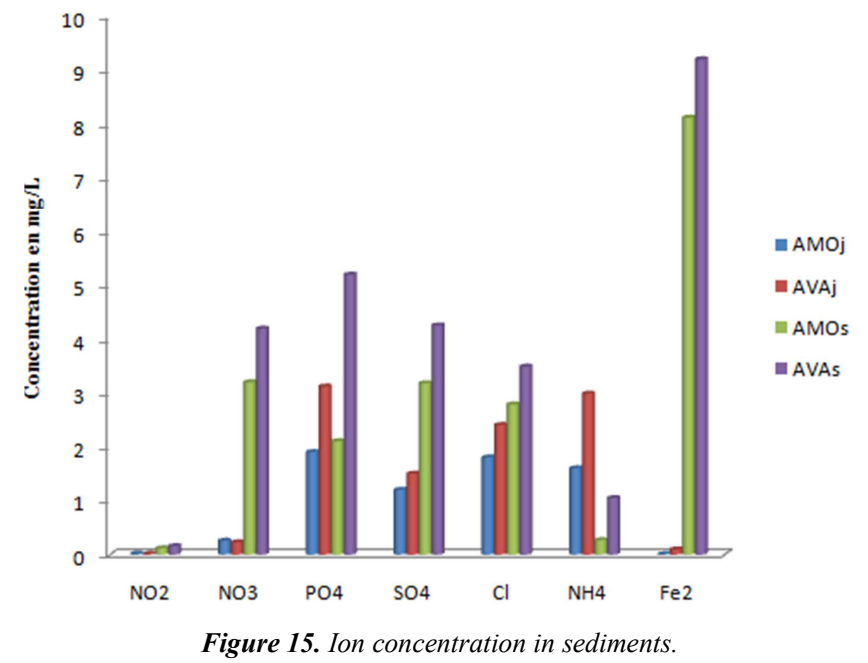

\section{Principal Component Analysis (PCA)}

The purpose of this review is to summarize the data structure described by quantitative variables, while obtaining uncorrelated factors between them. The principal component analysis was performed on both samples studied.

The 2 factors F1 and F2 explain $66.65 \%$ of the variances of water samples (Figure 16). It is observed that: the $\mathrm{pH}$, Conductivity, Turbidity, $\mathrm{BOD}_{5}$, the $\mathrm{PO}_{4}{ }^{3-}, \mathrm{NH}_{4}{ }^{+}, \mathrm{Cl}^{-}, \mathrm{SO}_{4}{ }^{2-}$, on the $\mathrm{Fe}^{2+}$ are the parameters shown on the axis F1 (Table 1) for a variance of $45.246 \%$.

By their homogeneous distribution along this axis and the presence of parameters such as Conductivity The Turbidity, $\mathrm{BOD}_{5}, \mathrm{pH}$, so there is mineralization $\left(\mathrm{NH}_{4}^{+}, \mathrm{Cl}^{-}\right.$, the $\mathrm{Fe}^{2+}$ mainly) in the area, we can observed that this axis represents parameters from human activities mainly agriculture, atmospheric deposition and discharges from the city. TSS, the $\mathrm{NO}_{3}{ }^{-}$are represented positively $\mathrm{F} 2$ and $\mathrm{O}_{2}$ negatively for a variation of $21.314 \%$. The strong contribution of TSS, $\mathrm{O}_{2}$ and $\mathrm{NO}_{3}^{-}$on this axis suggests a source of effluent from slaughterhouses Farcha.

For samples of the sediment, both F1 and F2 factors represent $88.476 \%$ of the total variance (Figure 17). Table 2 show that the factor F1 represents a variance of $69.49 \%$ includes the $\mathrm{NO}_{3}^{-}, \mathrm{Fe}_{2}^{+}$, the $\mathrm{PO}_{4}^{3-}, \mathrm{Cl}^{-}$having a high contribution. $\mathrm{NH}_{4}^{+}$and $\mathrm{NO}_{2}^{-}$(negatively) have a significant contribution. All these nutrients are original effluent from the slaughterhouse Farcha. They would be much more related to agriculture in the area N'Guéli rice mill and the heavy traffic of releases of facilities (Novotel, Meridien HGNR) and atmospheric deposition from air traffic from the international airport of N'Djaména. The factor F2 is marked by the strong contribution of original $\mathrm{SO}_{4}{ }^{2-}$ would much effluent from slaughterhouses Farcha because the levels are higher $\mathrm{SO}_{4}{ }^{2-}$ EXUj and EXUs. 


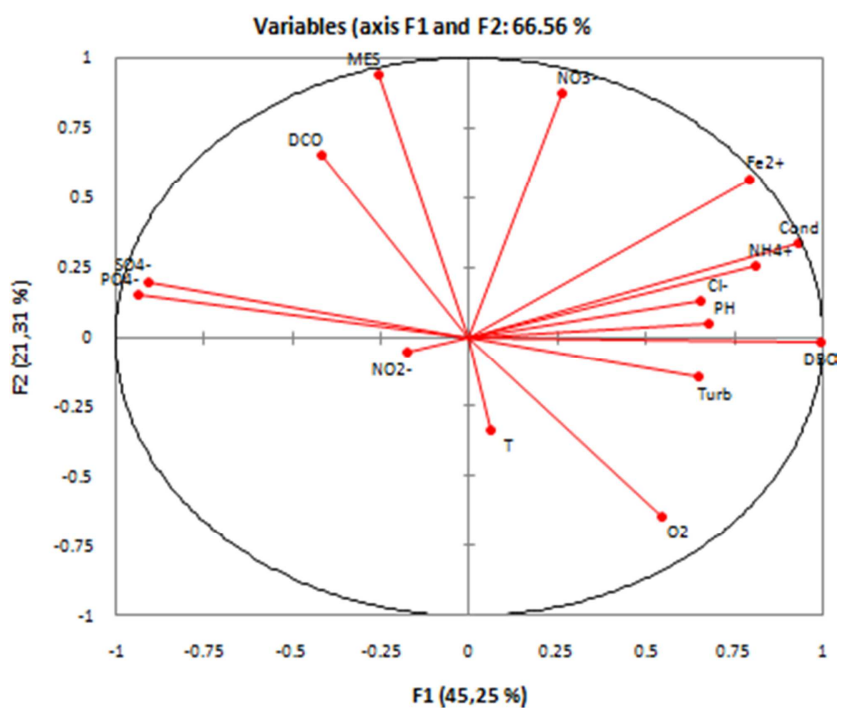

Figure 16. Correlation circle water samples (F1 vs. F2).

Table 1. Variable contributions for F1 and F2 factors in the waters of the Chari River.

\begin{tabular}{lll}
\hline & F1 & F2 \\
\hline $\mathrm{T}^{\circ} \mathrm{C}$ & 0.059 & -0.331 \\
$\mathrm{pH}$ & 0.678 & 0.048 \\
Conductivity & 0.932 & 0.335 \\
Turbidity & 0.648 & -0.146 \\
$\mathrm{DCO}$ & -0.416 & 0.653 \\
$\mathrm{DBO}$ & & -0.020 \\
$\mathrm{MES}$ & 0.994 & 0.940 \\
$\mathrm{O}_{2}$ & -0.257 & -0.640 \\
$\mathrm{NO}_{2}{ }^{-}$ & 0.547 & -0.052 \\
$\mathrm{NO}_{3}{ }^{-}$ & -0.174 & 0.875 \\
$\mathrm{PO}_{4}{ }^{3-}$ & 0.260 & 0.150 \\
$\mathrm{NH}_{4}{ }^{+}$ & -0.938 & 0.252 \\
$\mathrm{Cl}^{-}$ & 0.808 & 0.127 \\
$\mathrm{SO}_{4}{ }^{2-}$ & 0.654 & 0.199 \\
$\mathrm{Fe}^{2+}$ & -0.905 & 0.568 \\
\hline
\end{tabular}

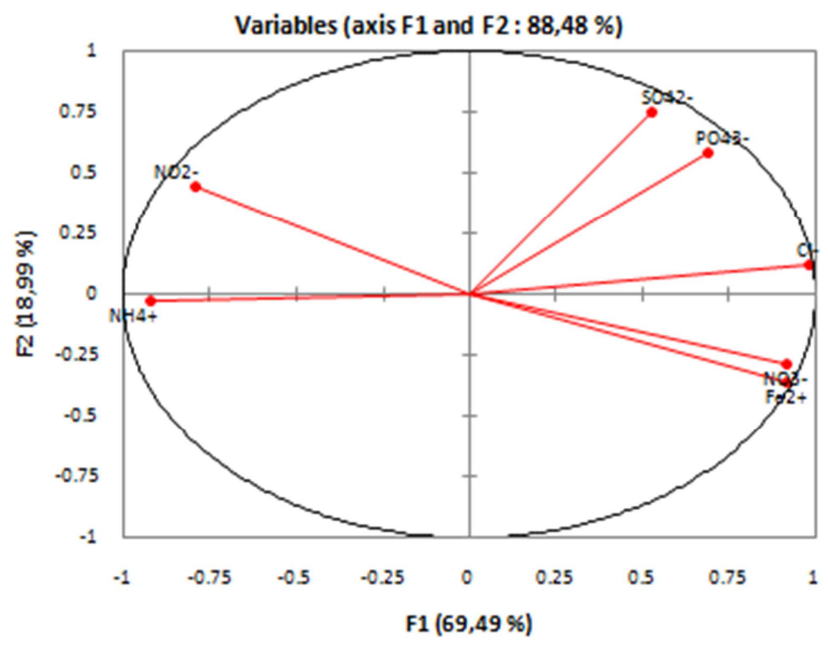

Figure 17. Correlation circle sediment samples (F1 vs F2).
Table 2. Variable contributions for F1 and F2 factors in sediments of the Chari River.

\begin{tabular}{lll}
\hline & F1 & F2 \\
\hline $\mathrm{NO}_{2}{ }^{-}$ & -0.792 & 0.446 \\
$\mathrm{NO}_{3}{ }^{-}$ & 0.917 & -0.284 \\
$\mathrm{PO}_{4}{ }^{--}$ & 0.692 & 0.581 \\
$\mathrm{SO}_{4}{ }^{2-}$ & 0.526 & 0,755 \\
$\mathrm{NH}_{4}{ }^{+}$ & -0.921 & -0.025 \\
$\mathrm{Fe}^{2+}$ & 0.914 & -0.356 \\
$\mathrm{Cl}-$ & 0.979 & 0.120 \\
\hline
\end{tabular}

\section{Conclusion}

Assessing the degree of Chari River pollution by waste water from slaughterhouses SMA/AFF Farcha was conducted during this study. The results of characterization of the three selected points of sampling generally, for the majority of the analysed parameters, pollution of river water is evident. The values obtained in TSS, $\mathrm{BOD}_{5}$ and $\mathrm{COD}$ at the outlet of Farcha slaughterhouses are high and are representative of a possible organic pollution. This pollution is representative of possible eutrophisation of the aquatic environment. The overall results show that the water of the Chari River at the outlet of slaughterhouses Farcha shows signs of degradation. The contents of nitrate, nitrite, iron, ammonia nitrogen in water and sediment are largely beyond the threshold set by WHO for water consumption and surfaces. High values in these nutrients are found at the outlet of the slaughterhouse demonstrating that slaughterhouses Farcha contribute to the pollution of the Chari River.

\section{References}

[1] Noumi G. B., Fabane F., Siéliéchi J. M., Speciation of phosphorus in the sediments sampled of lake Dang, Ngaoundere - Cameroon, Environmental Science and Pollution Research, 2015, 22 (4), 3098-3106.

[2] Siéliéchi J. M., Noumi G. B., Fadimatou M., Ali A., Kapseu C., Speciation of heavy metals in sediments sampled from different pollution sources of lake Dang, Ngaoundere Cameroon, International Journal of Environment Protection, 2013, 2 (3), 10-19.

[3] Tchoroun M, Noumi G. B., Tchadanaye N. M., Dangwang D. J. M., Heavy Metals Pollution Level in Water, Fish and Sediments from the Logone River Within Moundou City (Chad), International Journal of Environmental Monitoring and Analysis, 2015; 3 (5): 275-28.

[4] Siéliéchi J. M., Dangwang Dikdim J. M., Noumi G.B., Speciation phosphorus in the sediments sampled of lake Bini, Ngaoundere - Cameroon, Environment Technology, 2014, 35 (14), 1831-1839.

[5] Abderahmane M. A., Profil National du Tchad sur la gestion des produits chimiques, Ministère de l'Environnement et de l'eau, République du Tchad, 2001, 101p.

[6] Moctar Ismaël, Etude de la chaine de valeur de la filière cuir au Tchad, 2010. 
[7] Athman M., Ettriqui A., Hassane A., Étude sur les abattoirs d'animaux de boucherie en Afrique centrale (CamerounCongo-Gabon-Tchad), Organisation des nations unies pour l'alimentation et l'agriculture, 2013, 70p.

[8] Ngaram N., Tchadanaye N. M., Merle A., Bauteri P., BaskaliBouregaa N, Caractérisation physicochimique des eaux du fleuve Chari au niveau de la ville de N'djaména (Tchad), Anales de l'Université de Ndjamena-Série C - $\mathrm{N}^{\circ} 05,2011$, $102 \mathrm{p}$.

[9] Rodier J, L'Analyse de l'Eau, 9 $9^{\text {ème }}$ édition, Dunod, Paris, 2009, 1579p.

[10] WHO, Global pollution and health results of related environmental monitoring, Global Environnement Monitoring system, WHO, 1987.

[11] Gomez E., Durillon C., Rofes G., Picot B., Phosphate adsorption and release from sediments of brackish lagoons: $\mathrm{pH}, \mathrm{O}_{2}$ and loading influence, Water Res., 1999, 33, 24372447.

[12] Sorme L., Lagerkvist R., Sources of heavy metals in urban wastewater in Stockholm, Sci. Total Environ., 2002, 298, 131145 .
[13] Belghyti D., Caractérisation physico-chimique des eaux usées d'abattoir en vue de la mise en œuvre d'un traitement adéquat: cas de Kénitra au Maroc, Afrique Science 05 (2), 2009, 199 216.

[14] Obaidy M. J. A. H., Adel H. T., Shahad R. Z., Environmental Assessment of heavy metal distribution in sediments of Tigris River within Baghdad, International Journal of Advanced Research, 2014, 2 (8), 947-952.

[15] Haoua A., Mahaman S.L., Abdou S.M, Évaluation des rejets d'eaux usées de la ville de Niamey dans le fleuve Niger, Afrique Science, 2011, 07 (2), 43-55.

[16] Thomas. O, (1995). Métrologie des eaux résiduaire. Ed. Cebedoc / Tec et Doc. 11, Liège - 75384, Paris.

[17] Hebert S., Legre S., Suivi de la qualité de l'eau des rivières et petits cours d'eau, Direction du suivi de l'état de l'environnement, Ministère de l'Environnement Gouvernement du Québec, 2000, 5p.

[18] Bliefert C., Perraud R., Chimie de l'environnement: air, eau, sols, déchets, $2^{\text {ème }}$ édition, Edition De Boeck Université, 2009, $478 \mathrm{p}$. 